\title{
Chemical composition, antioxidant and antimicrobial activity of phenolic compounds extracted from wine industry by-products
}

\author{
Vanessa Silva $^{\mathrm{a}, \mathrm{b}, \mathrm{c}, \mathrm{d}}$, Gilberto Igrejas ${ }^{\mathrm{b}, \mathrm{c}, \mathrm{d}}$, Virgílio Falco ${ }^{\mathrm{e}}$, Teresa P. Santos ${ }^{\mathrm{e}}$, Carmen Torres ${ }^{\mathrm{f}}$, \\ Ana M.P. Oliveira ${ }^{\mathrm{g}}$, José Eduardo Pereira ${ }^{\mathrm{a}, \mathrm{h}}$, Joana S. Amaral ${ }^{\mathrm{i}, \mathrm{j}}$, Patrícia Poeta ${ }^{\mathrm{a}, \mathrm{d}, *}$ \\ ${ }^{a}$ Department of Veterinary Sciences, University of Trás-os-Montes and Alto Douro (UTAD), Vila Real, Portugal \\ b Department of Genetics and Biotechnology, Functional Genomics and Proteomics' Unit, University of Trás-os-Montes and Alto Douro, Vila Real, Portugal \\ c Functional Genomics and Proteomics Unit, University of Trás-os-Montes and Alto Douro (UTAD), Vila Real, Portugal \\ d Associated Laboratory for Green Chemistry (LAQV-REQUIMTE), University NOVA of Lisbon, Caparica, Portugal \\ e Centro de Química-Vila Real (CQ-VR), University of Trás-os-Montes and Alto Douro, Vila Real, Portugal \\ ${ }^{\mathrm{f}}$ Área de Bioquímica y Biología Molecular, Universidad de La Rioja, Logroño, La Rioja, Spain \\ ${ }^{g}$ Faculty of Veterinary Medicine, University Lusófona de Humanidades e Tecnologias, Campo Grande 376, 1749-024, Lisboa, Portugal \\ ${ }^{\text {h }}$ CECAV, Vila Real, Portugal \\ ${ }^{\text {i }}$ REQUIMTE-LAQV, Faculty of Pharmacy, University of Porto, Rua de Jorge Viterbo Ferreira 228, 4050-313, Porto, Portugal \\ ${ }^{\mathrm{j}}$ Centro de Investigação de Montanha (CIMO), Polytechnic Institute of Bragança, Campus de Santa Apolónia, 5300-253, Bragança, Portugal
}

\section{A R T I C L E I N F O}

\section{Keywords:}

Polyphenols

Winery by-products

Antioxidant activity

Antibacterial activity

Resistant bacteria

\begin{abstract}
A B S T R A C T
Winery by-products are a rich source of polyphenols, which have proven to have several beneficial biological properties, such as, antioxidant and antimicrobial activities. Therefore, this study aimed the extraction of polyphenols from winery by-products of two Portuguese red grape varieties, Touriga Nacional and Preto Martinho, and evaluate their phenolic profile, antioxidant properties and antimicrobial activity against antibiotic resistant bacteria. The polyphenols were extracted from the grapes' skins, seeds and stems. Extracts were analysed for total phenolic, anthocyanin and tannin contents, and the polyphenol profile was determined by High Performance Liquid Chromatography. The antioxidant activity of the extracts was determined by ABTS ${ }^{+}$ and DPPH methods. Antimicrobial susceptibility assay was performed using Kirby-Bauer disc diffusion method. Preto Martinho variety presented a higher polyphenolic content than Touriga Nacional. Malvidin 3-O-glucoside was the most abundant compound found in the skins extracts in both varieties. The main phenolic compound found in the seeds and stems extracts was catechin. From the several flavonols quantified, rutin was the most abundant. For both varieties, the seeds extracts showed the highest antioxidant and antimicrobial properties, followed by the stems extracts. The extracts showed antibacterial activity against all tested strains except on gram-negative bacteria Salmonella enteritidis, Escherichia coli and Pseudomonas aeruginosa. These results show that, natural products, such as polyphenols, may represent a source for the development of novel antimicrobials to combat gram-positive resistant bacteria and possibly be used as natural food preservatives. However, they were not effective against gram-negative resistant bacteria which shows that polyphenols, alone, might not substitute antibiotics.
\end{abstract}

\section{Introduction}

Grape (Vitis vinifera L.) is one of the most cultivated crops in the world, representing a production of more than 77 million tonnes in 2016, most of which is directed towards wine production (FAOSTAT, 2017). As part of the winemaking process, a large amount of waste is obtained, corresponding to approximately $20 \%$ of grapes' weight (Schieber, 2017). Grape pomace, including skins, stems and seeds, is frequently regarded as an environmental problem, due to its negative impact when disposed, or as an undervalued product, being used as a fertilizer or as animal feed (Beres et al., 2017). Although the pomace can be used for ethanol or grape seed oil production, several interesting and bioactive compounds still remain in its composition, turning this waste an interesting product with added-value in the context of circular economy. In this sense, grapes represent not only a source of nutrition, but also of several compounds with beneficial properties in the

\footnotetext{
* Corresponding author. Patrícia Alexandra Curado Quintas Dinis Poeta Laboratório Associado for Green Chemistry (LAQV-REQUIMTE), University of Trás-os-Montes and Alto Douro, 5000-911, Vila Real, Portugal.

E-mail address: ppoeta@utad.pt (P. Poeta).
} 
antimicrobial, antioxidant and anti-inflammatory standpoint. In particular, grapes are rich in polyphenols, a group of compounds frequently found in plants as products of their secondary metabolism. In the grape berry, some polyphenols, such as anthocyanins, are located mainly in the skins, while others such as, catechins are present in the skins, seeds and stems (Jordão \& Correia, 2012). Secondary metabolites have a great importance in the evolution of different plant lineages, since they address specific needs of plant physiology and morphology, but also have several functions including protecting the plant against bacteria, UV-radiation, stress situations (nutrient deficiency, low temperatures), among others (Boudet, 2007). Distinct plants synthesize different concentrations of numerous polyphenols since their ability to produce these compounds have changed over evolutionary time in order to overcome the environmental challenges (Boudet, 2007). Polyphenols have been studied in-depth over the last years since they exhibit a wide range of physiological properties such as antioxidant, anti-mutagenic, anti-inflammatory, anti-carcinogenic and antimicrobial activity (Dykes \& Rooney, 2007; Louli, Ragoussis, \& Magoulas, 2004; Quideau, Deffieux, Douat-casassus, \& Pouysøgu, 2011; Uttara, Singh, Zamboni, \& Mahajan, 2009).

Among the numerous applications of polyphenols, its use as natural preservatives has recently become an area of growing interest (Schieber, 2017). Additionally, it should also be considered that the emergence of drug resistant bacteria worldwide is becoming a threat to human health, which may lead the humankind back to the pre-antibiotic era, where small infections led to death (Davies \& Davies, 2010). Therefore, it is increasingly necessary to investigate and develop new effective antimicrobials. Several studies have been performed so far regarding the antimicrobial activity of natural plant-derived compounds, however, only a few studies were conducted with antibiotic resistant bacteria. Phenolic compounds have proved to have a high effect on bacteria, mainly because they cause structural or functional damage to the bacterial cell membrane (Aleksic \& Knezevic, 2014). A potential and cheap source of these compounds are the agro-industrial by-products. The list of compounds to check in plant-food by-products is almost endless since the secondary metabolites usually found in industry by-products, such as phenolics, tannins, alkaloids and terpenoids, have a great number of subclasses of active compounds(GuilGuerrero, Ramos, Moreno, Zúñiga-Paredes, \& Carlosama-Yepez, 2016). The winery by-products, namely grape pomace, represent a rich source of these compounds.

Currently, winemaking contributes significantly to the economy of several countries and $60 \%$ of the total wine production is made by European Union countries. Among those, Portugal is the fifth largest EU wine producer, with a production of more than 600 thousand tonnes in 2014 (FAOSTAT, 2017). Considering that winery by-products, such as skins, seeds and stems, account for $25-35 \mathrm{~kg} / \mathrm{hL}$ of produced wine (Prozil, Evtuguin, Silva, \& Lopes, 2014) and that they represent a suitable and inexpensive source of compounds with potential antimicrobial activity, the main goal of this work was to evaluate the phenolic compounds composition of different constituents of grape pomace, namely skins, seeds and stems, and assess its antimicrobial activity against several antibiotic resistant bacteria. For this purpose, polyphenols were extracted from the winery by-products (skins, seeds and stems) of two Portuguese red grape varieties, Touriga Nacional, one of the most representative cultivars in Douro region, and Preto Martinho, a cultivar also used in Douro region, presenting darker grapes when compared with Touriga Nacional, and for which no studies are available so far. The prepared extracts were evaluated for their phenolic profile, antioxidant properties and antimicrobial activity against antibiotic resistant bacteria.

\section{Material and methods}

\subsection{Plant material}

Plant material used includes stems, seeds and skins of two Portuguese red grape varieties: Touriga Nacional and Preto Martinho. Grapes were collected from Quinta das Carvalhas, Pinhão (Região Demarcada do Douro, Sub-região Cima Corgo) during the harvest season in September of 2016. All samples were freeze-dried, millpowdered and stored in a desiccator.

\subsection{Extraction of polyphenols}

The polyphenolic constituents from grape skins, seeds and stems were extracted using water/ethanol (50:50) mixture. Two grams of powder of each sample was extracted with $100 \mathrm{~mL}$ of solvent by stirring for $2 \mathrm{~h}$ followed by sonication during $5 \mathrm{~min}$. The samples were centrifuged at $10000 \mathrm{~g}$ for $15 \mathrm{~min}$ and the pellet was re-extracted. The supernatants were collected, and the solvents evaporated under vacuum on rotary evaporator at $40^{\circ} \mathrm{C}$. Finally, the obtained dry residues were weighted and redissolved in dimethyl sulfoxide (DMSO) to a final concentration of $100 \mu \mathrm{g} / \mathrm{mL}$. Extraction was done in duplicate for each sample.

\subsection{Determination of total phenolic and anthocyanin contents}

The total phenols and total anthocyanins were determined spectrophotometrically according to Connor, Luby, and Tong (2002) with modifications. Quartz crystal cuvettes were used for every assay and the reference solution was DMSO.

The total amount of phenols and of anthocyanins in seeds, skins and stems extracts were determined by adding $200 \mu \mathrm{L}$ of the extracts to $3.8 \mathrm{~mL}$ of $\mathrm{HCl} 1.0 \mathrm{M}$. The mixture was incubated at room temperature for $3 \mathrm{~h}$. Absorbances were measured at $520 \mathrm{~nm}$ to determine the anthocyanin content and at $280 \mathrm{~nm}$ to determine the total phenol content.

Each determination was performed in triplicate and results expressed as mean \pm standard deviation (SD).

\subsection{Determination of tannin content}

Total tannin content was determined as previously described by Sarneckis, Dambergs, Jones, Mercurio, and Herderich (2006) with modifications (Sarneckis et al., 2006). Methyl cellulose solution $(0.04 \%)$ was prepared according to the manufacturer's instructions.

\subsubsection{Treatment sample}

Six hundred microliters of methyl cellulose solution $(0.04 \%)$ was added to each sample $(50 \mu \mathrm{L})$ in a $2 \mathrm{~mL}$ centrifuge tube which was inverted several times and allowed to stand for $2-3 \mathrm{~min}$ at room temperature. Then, $400 \mu \mathrm{L}$ of saturated ammonium sulphate solution was added and the volume was made up with water to $2 \mathrm{~mL}$. The solution was incubated at room temperature for $10 \mathrm{~min}$, and then centrifuged for $15 \mathrm{~min}$ at $10000 \mathrm{~g}$. The absorbance was measured at $280 \mathrm{~nm}$.

\subsubsection{Control sample}

In a $2 \mathrm{~mL}$ centrifuge tube, $400 \mu \mathrm{L}$ of saturated ammonium sulphate solution was added to $30 \mu \mathrm{L}$ of each sample and the volume was made up with deionized water and mixed by tube inversion. The solution was allowed to stand at room temperature for $10 \mathrm{~min}$ and then centrifuged for $15 \mathrm{~min}$ at $10000 \mathrm{~g}$. Methyl cellulose solution was not used and instead it was used deionized water. The absorbance was measured at $280 \mathrm{~nm}$.

\subsection{HPLC-DAD analysis}

All samples were analyzed on a reversed phase HPLC unit (Gilson) 
using an Ultimate 300 solvent delivery system equipped with a Surveyor PDA plus detector (Thermo Finnigan, San Jose, CA, USA). The compounds separation was performed by gradient elution on an ACE 5 C18 column $(5 \mu \mathrm{m}$ particle size; $250 \mathrm{~mm} \times 4.6 \mathrm{~mm})$ using a mobile phase of $0.1 \%(\mathrm{v} / \mathrm{v})$ trifluoroacetic acid (TFA) inwater (eluent A) and $0.1 \%$ TFAin acetonitrile (eluent B) using a linear gradient of $20-100 \%$ eluent B in $60 \mathrm{~min}$. Phenolic compounds were identified by comparing retention times and UV-vis spectra with the available reference compounds and/or UV-vis spectra from the literature (Ferreira et al., 2016, 2017). Compounds quantification in the extracts was performed by the external standard method. Flavan-3-ols, vannilic and gallic acids were quantified at $280 \mathrm{~nm}$, hydroxycinnamic derivatives and resveratrol at $320 \mathrm{~nm}$, flavonols at $350 \mathrm{~nm}$ and anthocyanins at $520 \mathrm{~nm}$.

\subsection{Determination of antioxidant activity}

The antioxidant activity was determined in vitro by measuring the free radical scavenging activity using ABTS (2,2-azino-di-(3-ethyl-benzothialozine-sulphonic acid)) and DPPH (2,2-diphenyl-1-picrylhydrazyl) as described previously (Hatano, Kagawa, Yasuhara, \& Okuda, 1988; Re Pellegrini, Proteggente, Pannala, \& Rice-Evans, 1999). Briefly, the ABTS + solution was prepared by the addition of $7 \mathrm{mM}$ ABTS to $2.45 \mathrm{mM}$ of potassium persulphate. This solution was mixed and allowed to stand in the dark for $12-16 \mathrm{~h}$ at room temperature in order to produce ABTS radical cation. The working solution of ABTS + was obtained by the dilution of the previously made ABTS solution with ethanol to an absorvance of 0.70 at $734 \mathrm{~nm}$. Each sample and Trolox standards were added to ABTS + solution and the absorvance was read $10 \mathrm{~min}$ after mixing. The percentage of inhibition was calculated by the following formula: $\%$ inhibition $=100 \times(\mathrm{A} 0-\mathrm{A}) / \mathrm{A} 0$ where $\mathrm{A} 0$ was the initial absorbance obtained by measuring the solvent absorvance, and $\mathrm{A}$ was the final absorbance of each tested sample at $734 \mathrm{~nm}$. The calibration curve between \% inhibition and Trolox $(100-2000 \mu \mathrm{M})$ solutions was then established. The radical-scavenging activity of each tested sample was expressed in Trolox equivalent antioxidant capacity (TEAC $\mu \mathrm{mol}$ Trolox/g).

For DPPH assay, different concentrations of the extracts were mixed with methanolic solution containing DPPH radicals $(6 \times 10-5 \mathrm{M})$ and left to stand for $60 \mathrm{~min}$ in the dark to obtain stable absorption values. The decrease of the DPPH radical was determined by measuring the absorption at $517 \mathrm{~nm}$ and the radical scavaging activity (RSA) was calculated as percentage of DPPH discoloration according to following the formula: RSA $\%=[(\mathrm{ADPPH}-\mathrm{AS}) / \mathrm{ADPPH}] \times 100$, in which the AS is the absorbance of the sample solution and ADPPH is the absorbance of the DPPH solution. The extract concentration providing $50 \%$ of radicals scavenging activity (EC50) was calculated from the graph of RSA\% against extract concentration.

All determinations were carried out in triplicate.

\subsection{Bacterial strains, culture media and growth conditions}

Antimicrobial susceptibility was tested against 8 multiresistant different bacterial species: Enterococcus faecalis (E. faecalis) vanB2-C3735 (López et al., 2012), Enterococcus faecium (E. faecium) vanA-C2302 (Jiménez et al., 2013), Escherichia coli (E. coli) C999 (CTX-M-15) (Ruiz et al., 2012), Klebsiella pneumoniae (K. pneumoniae) C1370 (CTX-M-15) (Ruiz et al., 2012), Pseudomonas aeruginosa (P. aeruginosa) C4660 (VIM2) (Garza-Ramos et al., 2008), Staphylococcus aureus (S. aureus) C5932 (MRSA CC398) (Benito et al., 2014), Staphylococcu epidermidis (S. epidermidis) C3658 (linezo-R) (Lozano et al., 2013) and Salmonella enteritidis (S. enteritidis) C4220; and 2 foodborne strains Listeria monocytogenes (L. monocytogenes) ATCC700302 and Bacillus cereus (B. cereus) ATCC1306. The strains are part of the University of La Rioja and University of Trás-os-Montes and Alto Douro collection. All bacterial strains were grown in BHI agar (Oxoid, UK) for $24 \mathrm{~h}$ at $37^{\circ} \mathrm{C}$. For the antimicrobial activity assay, Müller-Hinton (Oxoid, UK) agar was used in the same previous conditions.

\subsubsection{Antibacterial susceptibility test}

Each bacterium was seeded onto BHI agar plates and grown for $24 \mathrm{~h}$ at $37^{\circ} \mathrm{C}$. The Müller-Hinton plates were inoculated with a swab dipped into a bacterial suspension with a turbidity equivalent to 0.5 McFarland standard. The antimicrobial susceptibility assay was performed using Kirby-Bauer disc diffusion method. The initial extract solution of $100 \mu \mathrm{g} / \mathrm{mL}$ was diluted with DMSO to 75, 50, 25 and $10 \mu \mathrm{g} /$ $\mathrm{mL}$. Twenty microliters of the extracts in several concentrations was loaded on sterile blank discs ( $6 \mathrm{~mm}$ diameter) and the discs were impregnated onto inoculated agar. Discs with antibiotics were used as positive controls and discs impregnated with DMSO were used as negative control. The plates were incubated at $37^{\circ} \mathrm{C}$ for $18-24 \mathrm{~h}$. The inhibition zones indicated the antimicrobial activity of the extracts and were measured with a ruler. The test was performed in triplicate.

\section{Results and discussion}

\subsection{Phenolic profiles analysis}

The Portuguese Port wine is produced from grapevine cultivars grown in Douro region. Both Touriga Nacional and Preto Marinho varieties are grown in Douro region and Touriga Nacional is widely used in Port wine production. As far as we know, this is the first report on the phenolic profile and antioxidant activity, as well as on antimicrobial activity of the Portuguese variety Preto Martinho. The results for total phenolic content (TPC), total anthocyanin content (TAC) and total tannin content (TTC) of the skins, stems and seeds of the two cultivars are presented in Table 1 . The skins extracts of Preto Martinho had higher concentrations of TPC $(360 \mu \mathrm{g} / \mathrm{mg})$, TAC $(65.8 \mu \mathrm{g} / \mathrm{mg})$ and TTC $(86.7 \mu \mathrm{g} / \mathrm{mg}$ ) than Touriga Nacional (TPC: $35.5 \mu \mathrm{g} / \mathrm{mg}$; TAC: $9.3 \mu \mathrm{g} / \mathrm{mg}$; TTC: $7.23 \mu \mathrm{g} / \mathrm{mg}$ ). These results were expected since Preto Martinho grapes are highly pigmented when compared to Touriga Nacional. Yet, the phenolic content of the grapes depends mainly on the variety and not only on the color of the grape (Yang, Martinson, \& Hai, 2009). The TPC of the seeds in both varieties were the highest of the three grape components analyzed which is in accordance with other studies (Cheng, Bekhit, Mcconnell, Mros, \& Zhao, 2012; Makris, Boskou, \& Andrikopoulos, 2007). However, Makris et al. (2007) studied the TPC of stem, skins and seeds of red grape varieties and obtained higher concentrations of TPC in stems than skins which differs from our results (Makris et al., 2007). As for the TPC and TTC of the stems extracts, once again Preto Martinho presented higher concentrations than Touriga Nacional. The distinct difference in TPC between the two Portuguese varieties reveals that Preto Martinho is a better source of polyphenols than Touriga Nacional.

The phenolic compounds extracted from the skins, seeds and stems of Touriga Nacional and Preto Martinho (PM) varieties were analyzed by reverse phase HPLC-DAD. Identification of the compounds was achieved by comparison of the retention times with characteristic UV/ vis spectra with standards and literature. Quantification was made by

\section{Table 1}

Total phenolic content (TPC), total anthocyanin content (TAC) and total tanin content (TTC) of the skins, seeds and stems of Touriga Nacional and Preto Martinho varieties (mean $\pm \mathrm{SD}, \mathrm{n}=3$ ).

\begin{tabular}{lllll}
\hline Wine varieties & & TPC $(\mu \mathrm{g} / \mathrm{mg})^{\mathrm{a}}$ & $\mathrm{TAC}(\mu \mathrm{g} / \mathrm{mg})^{\mathrm{a}}$ & TTC $(\mu \mathrm{g} / \mathrm{mg})^{\mathrm{a}}$ \\
\hline \multirow{2}{*}{ Touriga Nacional } & Skins & $35.5 \pm 1.8$ & $9.3 \pm 1.1$ & $7.23 \pm 2.1$ \\
& Seeds & $261.3 \pm 7.0$ & & $33.94 \pm 8.7$ \\
& Stems & $45.9 \pm 10.7$ & & $7.76 \pm 1.61$ \\
Preto Martinho & Skins & $360.2 \pm 2.5$ & $65.8 \pm 8.1$ & $86.71 \pm 6.3$ \\
& Seeds & $363.0 \pm 0.5$ & & $56.32 \pm 0$ \\
& Stems & $226.8 \pm 6.9$ & & $22.15 \pm 1.9$ \\
\hline
\end{tabular}

${ }^{\text {a }}$ Values expressed as $\mu \mathrm{g}$ of epicatechin equivalents/mg of residue. 
Table 2

Polyphenolic compounds ( $\mu \mathrm{g} / \mathrm{mg}$ of residue) fund in the grape varieties and their retention times.

\begin{tabular}{|c|c|c|c|c|c|c|c|}
\hline & \multirow{2}{*}{$\begin{array}{l}\lambda_{\max } \\
(\mathrm{nm})\end{array}$} & \multicolumn{3}{|c|}{ Preto Martinho } & \multicolumn{3}{|c|}{ Touriga Nacional } \\
\hline & & Skins & Stems & Seeds & Skins & Stems & Seeds \\
\hline gallic acid & 280 & 0.8 & 11.5 & 0.3 & 0.6 & 10.5 & 6.7 \\
\hline$o$-coumaric acid & 320 & n.d. ${ }^{\text {a }}$ & 4.55 & n.d. ${ }^{\text {a }}$ & 0.1 & 4.9 & n.d. ${ }^{\text {a }}$ \\
\hline vanillic acid & 280 & 0.7 & 24.9 & 0.5 & 0.4 & 15.9 & 1.5 \\
\hline neochlorogenic acid & 320 & 2.7 & 0.37 & n.d. ${ }^{\mathrm{a}}$ & 1.0 & 0.5 & n.d. ${ }^{\mathrm{a}}$ \\
\hline chlorogenic acid & 320 & 13.3 & 5.2 & n.d. ${ }^{\mathrm{a}}$ & 4.0 & 4.2 & n.d. ${ }^{\mathrm{a}}$ \\
\hline cyanidin 3-O-glucoside & 520 & 98.1 & n.d. ${ }^{a}$ & n.d. ${ }^{a}$ & 39.4 & n.d. ${ }^{a}$ & n.d. ${ }^{a}$ \\
\hline catechin & 280 & 55.8 & 38.7 & 17.2 & 29.8 & 29.3 & 7.7 \\
\hline$m$-coumaric acid & 320 & 7.2 & 0.7 & n.d. ${ }^{a}$ & 1.3 & 0.7 & n.d. ${ }^{\text {a }}$ \\
\hline peonidin 3-O-glucoside & 520 & 117.3 & n.d. ${ }^{a}$ & n.d. ${ }^{a}$ & 53.2 & n.d. ${ }^{a}$ & n.d. ${ }^{a}$ \\
\hline protocatechic acid & 280 & 7.2 & 11.3 & 2.1 & 2.3 & 6.1 & 6.0 \\
\hline epicatechin & 280 & 12.0 & 15.5 & 25.5 & 23.5 & 15.5 & 11.2 \\
\hline$p$-coumaric acid & 320 & 5.3 & 34.3 & n.d. ${ }^{\mathrm{a}}$ & 29.7 & 27.0 & n.d. ${ }^{a}$ \\
\hline malvidin 3-O-glucoside & 520 & 464.9 & n.d. ${ }^{\mathrm{a}}$ & n.d. ${ }^{a}$ & 178.8 & n.d. ${ }^{a}$ & n.d. ${ }^{a}$ \\
\hline gallocatechin gallate & 280 & 3.8 & 18.39 & 7.6 & 4.7 & 9.7 & 2.9 \\
\hline $\begin{array}{l}\text { quercetin-3-O- } \\
\text { rutinoside }\end{array}$ & 370 & 9.8 & 27.3 & 18.1 & 27.0 & 13.6 & n.d. ${ }^{a}$ \\
\hline $\begin{array}{l}\text { quercetin 3-O- } \\
\text { galactoside }\end{array}$ & 370 & 4.4 & 0.7 & 1.3 & 5.8 & n.d. ${ }^{\text {a }}$ & n.d. ${ }^{a}$ \\
\hline $\begin{array}{l}\text { quercetin 3-O- } \\
\text { glucoside }\end{array}$ & 370 & 3.8 & 1.3 & 1.7 & 17.1 & n.d. ${ }^{\text {a }}$ & n.d. ${ }^{\text {a }}$ \\
\hline catechin gallate & 280 & 0.8 & 6.3 & 9.0 & 5.8 & 6.8 & 0.7 \\
\hline luteolin 7-O-glucoside & 370 & 5.9 & 2.9 & 1.7 & 5.1 & 0.5 & 1.1 \\
\hline luteolin 7-O-rutinoside & 370 & 4.6 & 1.7 & n.d. ${ }^{\mathrm{a}}$ & 9.6 & 0.6 & 0.7 \\
\hline trans-resveratrol & 320 & 8.4 & 7.4 & 15.4 & 4.7 & 4.6 & 1.0 \\
\hline $\begin{array}{l}\text { quercetina-3-o- } \\
\text { rhamnoside }\end{array}$ & 370 & n.d. ${ }^{\text {a }}$ & n.d. ${ }^{\text {a }}$ & n.d. ${ }^{\text {a }}$ & n.d. ${ }^{\text {a }}$ & 0.6 & n.d. ${ }^{\text {a }}$ \\
\hline ferulic acid & 320 & 1.5 & 13.8 & 11.8 & 5.1 & 19.6 & 3.1 \\
\hline
\end{tabular}

${ }^{\text {a }}$ Not detected.

calibration curves of external standards and is expressed in catechin equivalents. The polyphenolic profiling of the two studied varieties revealed a total of twenty-four polyphenols, comprising phenolic acids, flavan-3-ols, flavonols, a stilbene and anthocyanins. The individual major phenolic compounds identified and quantified in the skins, seeds and stems of each variety are shown in Table 2. Malvidin 3-O-glucoside was the most abundant polyphenol in the grape skins of both varieties, being in a higher concentration in the extract of Preto Martinho $(464.9 \mu \mathrm{g} / \mathrm{mg})$ than in the extract of Touriga Nacional $(178.8 \mu \mathrm{g} / \mathrm{mg})$. Peonidin 3-O-glucoside was the second compound more abundant in skin extracts of both Preto Martinho $(117.3 \mu \mathrm{g} / \mathrm{mg})$ and Touriga Nacional $(53.2 \mu \mathrm{g} / \mathrm{mg}$ ) followed by ferulic acid (PM: $115.5 \mu \mathrm{g} / \mathrm{mg}$; TN: $51.1 \mu \mathrm{g} / \mathrm{mg}$ ) and cyanidin 3-O-glucoside (PM: $98.1 \mu \mathrm{g} / \mathrm{mg}$; TN: $39.4 \mu \mathrm{g}$ / $\mathrm{mg}$ ). The compounds with highest concentration are similar between the grape cultivars which may be due to the fact that both varieties were grown in the same region in the same conditions. Despite this, Preto Martinho skins extracts have a higher concentration of phenolic compounds in general than Touriga Nacional. Of all anthocyanins, cyanidin 3-O-glucoside was present in the lowest concentration in both varieties, which can be due to cyanidin being a precursor in the biosynthesis of other anthocyanins (Novak, Janeiro, Seruga, \& Oliveirabrett, 2008). Rutin (quercetin-3-O-rutinoside), was the most abundant compound of the flavonol group in both varieties, being in a higher concentration in Touriga Nacional $(27.0 \mu \mathrm{g} / \mathrm{mg})$ than Preto Martinho $(9.8 \mu \mathrm{g} / \mathrm{mg})$. Other studies have found similar results for Touriga Nacional (Novak et al., 2008). The main phenolic compounds found in the seed extracts were catechin $(17.2 \mu \mathrm{g} / \mathrm{mg}$ in Preto Martinho and $7.7 \mu \mathrm{g} /$ $\mathrm{mg}$ in Touriga Nacional) and epicatechin $(15.5 \mu \mathrm{g} / \mathrm{mg}$ in Preto Martinho and $11.2 \mu \mathrm{g} / \mathrm{mg}$ in Touriga Nacional) which is comparable to the literature (Cheng et al., 2012; Hatzidimitriou, Nenadis, \& Tsimidou, 2007). Both varieties had higher concentration of epicatechin than catechin. Although some studies made with varieties from southern Europe found a higher concentration of catechin than epicatechin in red grape varieties (Zhu, Zhang, \& Lu, 2012), the opposite was described in other studies (Hatzidimitriou et al., 2007). Thus, these variations may be consequence of the genetic differences between cultivars, the light intensity, the composition of the soil, the region, among others (Topalovic \& Mikulic-Petkovsek, 2010). The following most abundant compound in Preto Martinho's seeds extract was trans-resveratrol $(15.4 \mu \mathrm{g} / \mathrm{mg})$ and for Touriga Nacional was gallic acid $(6.7 \mu \mathrm{g} / \mathrm{mg})$. In what concerns grape stems, only a few studies have investigated the phenolic composition of this type of winery by-product (Goutzourelas et al., 2015; Vázquez-Armenta et al., 2017). Catechin was the most abundant compound in both varieties being the concentration of this compound higher in Preto Martinho $(38.7 \mu \mathrm{g} / \mathrm{mg})$ than Touriga Nacional $(29.3 \mu \mathrm{g} / \mathrm{mg})$ stems. The second compound with the highest concentration was p-coumaric acid in both Preto Martinho $(34.3 \mu \mathrm{g} /$ $\mathrm{mg})$ and Touriga Nacional $(27.0 \mu \mathrm{g} / \mathrm{mg})$ followed by rutin $(27.3 \mu \mathrm{g} / \mathrm{mg})$ in Preto Martinho and ferulic acid $(19.6 \mu \mathrm{g} / \mathrm{mg})$ in Touriga Nacional. Grape stems are essentially constituted by lignin, tannins, cellulose and hemicelluloses (Prozil et al., 2014). Lignin is made of phenolics acids such as $p$-coumaric acid, ferulic acid, among others (Adeboye, Bettiga, \& Olsson, 2014). The concentration of epicatechin in the stems extracts of both varieties was $15.5 \mu \mathrm{g} / \mathrm{mg}$ which is in accordance with another study that detected a reduced concentration of epicatechin in comparison with catechin in stems of red grape varieties from Greece (Apostolou et al., 2013).

\subsection{Antioxidant activity}

The antioxidant activity of skins, seeds and stems of Preto Martinho and Touriga Nacional was evaluated using the ABTS and DPPH methods. The free radical-scavenging assay using DPPH radical is widely used as a screening assay in the determination of antioxidant capacity of different plant extracts since it provides information on how capable an antioxidant is in preventing reactive radical species from reaching several components of the biological systems. DPPH (Katalinic et al., 2010). Results showed that Preto Martinho variety had greater antioxidant activity than Touriga Nacional. Regarding the results obtained from the ABTS assay, the total average values in Touriga Nacional were 33.2, 185.2 and 59.0 and in Preto Martinho were 80.6, 206.3 and $97.9 \mu \mathrm{mol}$ Trolox equivalent per $\mathrm{g}$ of residue in skins, seeds and stems, respectively (Table 3). The results of the DPPH assay, measured in effective concentration providing 50\% inhibition (EC50), were in good agreement with those of the ABTS assay, since an higher antioxidant capacity was also found for the seeds extracts, followed by stems and skins. In both varieties, a higher TPC was determined for the seeds extracts when compared tothe skins and stems extracts, which most probably explains the higher antioxidant activity observed for the former. This is in good agreement with previous studies that evaluated the antioxidant capacity and TPC of several grape varieties, and reported a high correlation between these parameters, pointing to the fact that the antioxidant activity of wines is mainly due to its phenolic compounds (Paixão, Perestrelo, Marques, \& Câmara, 2007; Rupasinghe \& Clegg, 2007). Doshi, Adsule, Banerjee, \& Oulkar, 2015 investigated

Table 3

Antioxidant activity of the skins, seeds and stems of Touriga Nacional and Preto Martinho varieties (mean value $\pm S D, n=3$ ).

\begin{tabular}{llll}
\hline Wine varieties & & ABTS $^{\mathrm{a}}$ & $\mathrm{DPPH}^{\mathrm{b}}$ \\
\hline Touriga Nacional & Skins & $33.2 \pm 2.0$ & $0.73 \pm 0.04$ \\
& Seeds & $185.2 \pm 5.9$ & $0.09 \pm 0.01$ \\
\multirow{3}{*}{ Preto Martinho } & Stems & $59.0 \pm 2.6$ & $0.25 \pm 0.01$ \\
& Skins & $80.6 \pm 3.1$ & $0.15 \pm 0.01$ \\
& Seeds & $206.3 \pm 7.7$ & $0.05 \pm 0.002$ \\
& Stems & $97.9 \pm 3.8$ & $0.13 \pm 0.02$ \\
\hline
\end{tabular}

${ }^{\text {a }}$ Expressed in $\mu \mathrm{mol}$ Trolox/g of residue.

b Expressed in effective concentration at which 50\% of DPPH radicals are scavenged $\left(\mathrm{EC}_{50}, \mathrm{mg} / \mathrm{mL}\right)$. 
Table 4

Minimum inhibitory concentration of grape skins, stems and seeds extracts of two Portuguese varieties.

\begin{tabular}{|c|c|c|c|c|c|c|}
\hline & \multicolumn{6}{|c|}{ MIC $(\mu \mathrm{g} / \mathrm{mL})$} \\
\hline & \multicolumn{4}{|c|}{ Touriga Nacional } & \multicolumn{2}{|l|}{ Preto Martinho } \\
\hline & Skins & Stems & Seeds & Skins & Stems & Seeds \\
\hline \multicolumn{7}{|l|}{ Gram-positive } \\
\hline S. epidermidis & 10 & 75 & 10 & 10 & 25 & 25 \\
\hline S. aureus & - & 100 & 50 & 75 & - & 10 \\
\hline E. faecalis & - & - & 50 & 25 & 50 & 10 \\
\hline E. faecium & 100 & 100 & 100 & - & 100 & - \\
\hline L. monocytogenes & 50 & 50 & 100 & 50 & 50 & 10 \\
\hline B. cereus & 100 & - & 10 & - & - & 50 \\
\hline \multicolumn{7}{|l|}{ Gram-negative } \\
\hline K. pneumoniae & 100 & - & 50 & - & 75 & 100 \\
\hline E. coli & - & - & - & - & - & - \\
\hline P. aeruginosa & - & - & - & - & - & - \\
\hline S. entereditis & - & - & - & - & - & - \\
\hline
\end{tabular}

the antioxidant capacity of the skins, seeds and stems extracts of two grape varieties, Pusa Navarang and Merlot, and found that in both cases the seeds presented the highest antioxidant activity. However, in Merlot extracts the stems present a higher antioxidant activity than the skins whereas the opposite was verified in Pusa Navarang extracts.

\subsection{In vitro antimicrobial tests}

The antimicrobial activity of skins, seeds and stems extracts was evaluated using the Kirby-Bauer disc diffusion method. The results for the minimum inhibitory concentration (MIC) are expressed in Table 4. All extracts showed antimicrobial activity with clear-cut inhibition zone. As expected, extracts from different parts of grapes exhibited different antibacterial effects. Total polyphenols content was directly proportional to the diameters of the inhibition zones which indicates that these compounds are responsible for antimicrobial effects. This is in line with the results obtained in other studies made with polyphenols extracted from winery by-products (Furiga, Lonvaud-funel, \& Badet, 2009; Katalinic et al., 2010). Nevertheless, it is important to notice that, in this study, unlike most studies, we used antibiotic resistant bacteria which have several mechanisms that confers them resistance to antibiotics and several natural compounds. There was no inhibitory effect of neither of the extracts on $S$. enteritidis, E. coli and P. aeruginosa at the concentrations tested, making $K$. pneumoniae the only gram-negative bacteria susceptible to the tested phenolic compounds. In fact, it has often been reported that polyphenolic extracts are more efficient against Gram-positive bacteria (Klančnik, Guzej, Kolar, Abramovič, \& Možina, 2009). Gram-negative bacteria have low susceptibility to polyphenols when compared to Gram-positive bacteria due to the repulsion between these compounds and the lipopolysaccharide present in the surfaces of gram-negative bacteria (Fattouch et al., 2007). Other studies have reported inhibitory effect of polyphenols on gram-negative bacteria, however, the concentrations used were higher than in our study (Butkhup, Chowtivannakul, Gaensakoo, Prathepha, \& Samappito, 2010; Taguri, Tanaka, \& Kouno, 2004). Among all bacteria tested, $S$. epidermidis was the most susceptible to the assayed polyphenols, followed by L. monocytogenes and S. aureus. Similar results have been reported in other studies that found Staphylococcus species to be the most susceptible bacteria to polyphenols (Szewczyk, Zidorn, Biernasiuk, Komsta, \& Granica, 2016; Xu et al., 2014; Yam, Shah, \& HamiltonMiller, 2006).

The seeds extracts from both varieties showed the highest antimicrobial activity, as evidenced by the inhibitory effect on 7 out of the 10 bacterial strains tested. Other studies have exposed that the seeds are the constituent of the grape with higher antimicrobial effect (Anastasiadi, Chorianopoulos, Nychas, \& Haroutounian, 2009; Nirmala
\& Narendhirakannan, 2011). Despite the fact that Preto Martinho seeds extract did not have inhibitory effect on E. faecium, the seeds extract of this variety still had a greater antibacterial activity than Touriga Nacional since in general it presents lower MICs (Table 4). Vaquero, Alberto, and de Nadra (2007) tested the antimicrobial activity of several non-flavonoid phenolic compounds usually present in wines and found out that gallic acid and vanillic acid had inhibitory effect on the growth of $E$. coli and $K$. pneumoniae being this effect higher on $K$. pneumoniae (Rodríguez Vasquero, Alberto, \& Manca de Nadra, 2007). These findings may explain our results since the seed extract of Touriga Nacional had higher concentrations of gallic acid and vanillic acid than Preto Martinho.

The skins extract of Touriga Nacional had a higher antibacterial effect than the stems extract of the same variety while in Preto Martinho extracts it was the opposite. Comparing the two varieties, Preto Martinho skin extracts had lower MICs than Touriga Nacional. The skins extract of Touriga Nacional was not able to inhibit the growth of $S$. aureus and E. faecalis, and Preto Martinho skins extract had no antimicrobial effect on $E$. faecium, B. cereus and $K$. pneumoniae at the concentrations tested. Nirmala and Narendhirakannan (2011) used higher concentrations of grape skins extract, in a range of $50-250 \mathrm{mg}$ / $\mathrm{mL}$, in order to get an inhibition zone with the disc-diffusion method for E. coli, K. pneumoniae, E. faecalis, S. aureus and P. aeruginosa.

Regarding the stem extracts, it has been reported that they have antimicrobial properties, however, these grape constituents have not been significantly investigated yet. In this study, the stems extract had the lowest antibacterial activity with MICs generally superior to the other extracts for the same bacteria. The Touriga Nacional stems extract had inhibitory effect on S. epidermidis, S. aureus, E. faecium and $L$. monocytogenes while Preto Martinho stems extract inhibit the growth of S. epidermidis, E. faecalis, E. faecium, L. monocytogenes and K. pneumoniae. L. monocytogenes, a pathogenic bacteria frequently associated to foodborne diseases, was inhibited by stems extracts of both grape varieties and the MIC of Touriga Nacional stems extract was the lowest of all bacteria inhibited by this extract. The antilisterial activity of red grapes stems have been reported before (Anastasiadi et al., 2009; Martin et al., 2012). Although in different concentrations, all the tested extracts were able to inhibit the growth of $L$. monocytogenes, thus highlighting the potential of these extracts as food preservatives.

In general, the polyphenols extracted from wine by-products of Touriga Nacional and Preto Martinho varieties exhibited a good antibacterial activity against several pathogenic bacteria resistant to antibiotics, presenting better results when compared, for instance, with those reported for other Vitis species grapes, such as muscadine grapes (Vitis rotundifolia) (Xu et al., 2014). The MIC of extracts obtained from muscadine grapes pomace were in general much higher (E. coli, MIC $=450-1519 \mathrm{mg} / \mathrm{L} ; S$. aureus, MIC $=67-152 \mathrm{mg} / \mathrm{L}$ ) than the ones obtained in the present study for Vitis vinifera grape varieties. The antibacterial activity of each extract is possibly due to the presence of different phenolic compounds which may have synergetic effect between them. Nevertheless, the structural chemistry of each polyphenol may also be responsible for the antimicrobial activity. Some authors have reported that the degree of polymerization and the number of hydroxyl groups might dictate the inhibitory effect of each phenolic compound (Taguri et al., 2004; Tesaki et al., 1999). Furthermore, the antimicrobial capacity of phenolic compounds could also be explained by adsorption to cell membranes, interaction with enzymes, substrate and metal ion deprivation (Scalbert, 1991).

\section{Conclusions}

Winery by-products are a great and cheap source of polyphenols, with both varieties investigated exhibiting high content of polyphenols. Nevertheless, Preto Martinho had greater polyphenolic, anthocyanin and tannin content than Touriga Nacional. As far as we know, the phenolic profile of Preto Martinho variety is reported for the first time. 
Grape seeds of both varieties were the richest in both total and individual phenolic content among the grape components studied and had the highest antioxidant capacity, consequently, it could be further evaluated as dietary supplements. The seeds extracts also had the greatest antibacterial activity and their high content in catechin, epicatechin and trans-resveratrol may be responsible for this effect. All gram-positive bacteria showed susceptibility to polyphenols extracted from winery by-products. From the gram-negative bacteria tested only $K$. pneumoniae showed susceptibility to the seeds extracts.

Natural compounds, such as polyphenols, act as antibacterial agents which may become useful therapeutic tools. However, these products alone might not substitute antibiotics, but rather to potentiate the effect of the antibiotic when used together. The extracts were also effective against foodborne bacteria which shows that polyphenols may have potential usefulness as food preservers. The skins, seeds and stems extracts had a very high number of different phenolic compounds. Therefore, in order to determine which polyphenol had inhibitory or the greater inhibitory effect, more studies will be carried out regarding the effect of each isolated polyphenol on resistant bacteria.

\section{Conflicts of interest}

None to declare.

\section{References}

Adeboye, P. T., Bettiga, M., \& Olsson, L. (2014). The chemical nature of phenolic compounds determines their toxicity and induces distinct physiological responses in Saccharomyces cerevisiae in lignocellulose hydrolysates. AMB Express, 4(46), 1-10. https://doi.org/10.1186/s13568-014-0046-7.

Aleksic, V., \& Knezevic, P. (2014). Antimicrobial and antioxidative activity of extracts and essential oils of Myrtus communis L. Microbiological Research, 169(4), 240-254. https://doi.org/10.1016/j.micres.2013.10.003.

Anastasiadi, M., Chorianopoulos, N. G., Nychas, G.-J., \& Haroutounian, S. A. (2009). Antilisterial activities of polyphenol-rich extracts of grapes and vinification byproducts. Journal of Agricultural and Food Chemistry, 57, 457-463.

Apostolou, A., Stagos, D., Galitsiou, E., Spyrou, A., Haroutounian, S., Portesis, N., ... Kouretas, D. (2013). Assessment of polyphenolic content, antioxidant activity, pro tection against ROS-induced DNA damage and anticancer activity of Vitis vinifera stem extracts. Food and Chemical Toxicology, 61, 60-68. https://doi.org/10.1016/j. fct.2013.01.029.

Benito, D., Go, P., Lozano, C., Estepa, V., Go, E., Zarazaga, M., et al. (2014). In Staphylococcus aureus of meat samples in Spain : Analysis of immune evasion cluster (IEC) genes. Foodborne Pathogens and Disease, 11(5), 354-356. https://doi.org/10. 1089/fpd.2013.1689.

Beres, C., Costa, G. N. S., Cabezudo, I., da Silva-James, N. K., Teles, A. S. C., Cruz, A. P. G., ... Freitas, S. P. (2017). Towards integral utilization of grape pomace from winemaking process: A review. Waste Management, 68, 581-594. https://doi.org/https:// doi.org/10.1016/j.wasman.2017.07.017.

Boudet, A. (2007). Evolution and current status of research in phenolic compounds. Phytochemistry, 68, 2722-2735. https://doi.org/10.1016/j.phytochem.2007.06.012.

Butkhup, L., Chowtivannakul, S., Gaensakoo, R., Prathepha, P., \& Samappito, S. (2010). Study of the phenolic composition of shiraz red grape cultivar (Vitis vinifera L.) cultivated in north-eastern Thailand and its antioxidant and antimicrobial activity. South African Journal for Enology and Viticulture, 31(2), 89-98.

Cheng, V. J., Bekhit, A. E. A., Mcconnell, M., Mros, S., \& Zhao, J. (2012). Effect of extraction solvent, waste fraction and grape variety on the antimicrobial and antioxidant activities of extracts from wine residue from cool climate. Food Chemistry, 134(1), 474-482. https://doi.org/10.1016/j.foodchem.2012.02.103.

Connor, A. M., Luby, J. J., \& Tong, C. B. S. (2002). Variability in antioxidant activity in blueberry and correlations among different antioxidant activity assays. Journal of the American Society for Horticultural Science, 127(2), 238-244.

Davies, J., \& Davies, D. (2010). Origins and evolution of antibiotic resistance, Vol. 74, 417-433. 3 https://doi.org/10.1128/MMBR.00016-10.

Doshi, P., Adsule, P., Banerjee, K., \& Oulkar, D. (2015). Phenolic compounds, antioxidant activity and insulinotropic effect of extracts prepared from grape (Vitis vinifera L) byproducts. Journal of Food Science \& Technology, 52(1), 181-190. https://doi.org/ 10.1007/s13197-013-0991-1.

Dykes, L., \& Rooney, L. W. (2007). Phenolic compounds in cereal grains and their health benefit. Cereal Foods World, 52(3), 105-111.

Fattouch, S., Caboni, P. I., Coroneo, V., Tuberoso, C., Angioni, A., Dessi, S., ... Cabras, P. (2007). Antimicrobial activity of tunisian quince ( cydonia oblonga miller ) pulp and peel polyphenolic extracts. Journal of Agricultural and Food Chemistry, 55, 963-969. https://doi.org/10.1021/jf062614e.

Ferreira, V., Fernandes, F., Carrasco, D., Hernandez, M. G., Pinto-Carnide, O., ArroyoGarcía, R., ... Castro, I. (2017). Spontaneous variation regarding grape berry skin color: A comprehensive study of berry development by means of biochemical and molecular markers. Food Research International, 97, 149-161. https://doi.org/https:// doi.org/10.1016/j.foodres.2017.03.050.

Ferreira, V., Fernandes, F., Pinto-Carnide, O., Valentão, P., Falco, V., Martín, J. P., ... Castro, I. (2016). Identification of Vitis vinifera L. grape berry skin color mutants and polyphenolic profile. Food Chemistry, 194, 117-127. https://doi.org/https://doi.org/ 10.1016/j.foodchem.2015.07.142.

Food and Agriculture Organization of the United Nations (2017). FAOSTAT database. ((n.d.). No Title) http://www.fao.org/faostat/en, Accessed date: December 2017.

Furiga, A., Lonvaud-funel, A., \& Badet, C. (2009). In vitro study of antioxidant capacity and antibacterial activity on oral anaerobes of a grape seed extract. Food Chemistry, 113(4), 1037-1040. https://doi.org/10.1016/j.foodchem.2008.08.059.

Garza-Ramos, U., Morfin-Utero, R., Sader, H., Jones, R., Hernandez, E., RodriguezNoriega, E., ... Silva-Sanchez, J. (2008). Metallo- " class 1 integron, in 95, from Pseudomonas aeruginosa clinical isolates from a hospital in Mexico. Antimicrobial Agents and Chemotherapy, 52(8), 2943-2946. https://doi. org/10.1128/AAC.00679-07.

Goutzourelas, N., Stagos, D., SPpanidis, Y., Liosi, M., Apostolou, A., Priftis, A., et al. (2015). Polyphenolic composition of grape stem extracts affects antioxidant activity in endothelial and muscle cells. Molecular Medicine Reports, 12(4), 5846-5856. https://doi.org/10.3892/mmr.2015.4216.

Guil-Guerrero, J. L., Ramos, L., Moreno, C., Zúñiga-Paredes, J. C., \& Carlosama-Yepez, M. (2016). Antimicrobial activity of plant-food by-products: A review focusing on the tropics. Livestock Science, 189, 32-49. https://doi.org/10.1016/j.livsci.2016.04.021.

Hatano, T., Kagawa, H., Yasuhara, T., \& Okuda, T. (1988). Two new flavonoids and other constituents in licorice Root: Their relative astringency and radical scavenging effects. Chemical \& Pharmaceutical Bulletin, 36(6), 2090-2097. https://doi.org/10. 1248/cpb.36.2090.

Hatzidimitriou, E., Nenadis, N., \& Tsimidou, M. Z. (2007). Food Chemistry Changes in the catechin and epicatechin content of grape seeds on storage under different water activity ( a w ) conditions. Food Chemistry, 105, 1504-1511. https://doi.org/10. 1016/j.foodchem.2007.05.032.

Jiménez, E., Ladero, V., Chico, I., Maldonado-Barragán, A., López, M., Martín, V., ... Rodríguez, J. M. (2013). Antibiotic resistance, virulence determinants and production of biogenic amines among enterococci from ovine, feline, canine, porcine and human milk. BMC Microbiology, 13(1), 288. https://doi.org/10.1186/1471-2180-13288.

Jordão, A. M., \& Correia, A. C. (2012). Relationship between antioxidant capacity, proanthocyanidin and anthocyanin content during grape maturation of Touriga nacional and tinta roriz grape varieties. South African Journal for Enology and Viticulture, 33(2), 214-224.

Katalinic, V., Mozina, S. S., Skroza, D., Generalic, I., Abramovic, H., Milos, M., ... Boban, M. (2010). Polyphenolic profile, antioxidant properties and antimicrobial activity of grape skin extracts of 14 Vitis vinifera varieties grown in Dalmatia (Croatia). Food Chemistry, 119, 715-723. https://doi.org/10.1016/j.foodchem.2009.07.019.

Klančnik, A., Guzej, B., Kolar, M. H., Abramovič, H., \& Možina, S. S. (2009). In vitro antimicrobial and antioxidant activity of commercial rosemary extract formulations. Journal of Food Protection, 72(8), 1744-1752. https://doi.org/10.4315/0362-028X72.8.1744.

López, M., Rezusta, A., Seral, C., Aspiroz, C., Marne, C., Aldea, M., ... Torres, C. (2012) Detection and characterization of a ST6 clone of vanB2-Enterococcus faecalis from three different hospitals in Spain. European Journal of Clinical Microbiology \& Infectious Diseases, 257-260. https://doi.org/10.1007/s10096-011-1303-1.

Louli, V., Ragoussis, N., \& Magoulas, K. (2004). Recovery of phenolic antioxidants from wine industry by-products. Bioresource Technology, 92(92), 201-208. https://doi.org/ 10.1016/j.biortech.2003.06.002.

Lozano, C., Aspiroz, C., Gómez-sanz, E., Tirado, G., Fortu, B., Zarazaga, M., et al. (2013). Caracterización de cepas de Staphylococcus epidermidis y S. haemolyticus resistentes a meticilina y linezolid en un hospital espa nol. Enfermedades Infecciosas y Microbiología Clínica, 31(3), 136-141.

Makris, D. P., Boskou, G., \& Andrikopoulos, N. K. (2007). Polyphenolic content and in vitro antioxidant characteristics of wine industry and other agri-food solid waste extracts. Journal of Food Composition and Analysis, 20, 125-132. https://doi.org/10. 1016/j.jfca.2006.04.010.

Martin, J., Porto, E., Correa, Alencar, S., Gloria, E., Cabral, I., \& Aquino, L. (2012). Antimicrobial potential and chemical composition of agro-industrial wastes. Journal of Natural Products, 5(2012), 27-36.

Nirmala, J., \& Narendhirakannan, R. T. (2011). In vitro antioxidant and antimicrobial activities of grapes ( Vitis Vinifera. L ). International Journal of Pharmacy and Pharmaceutical Sciences, 3(4), 242-249.

Novak, I., Janeiro, P., Seruga, M., \& Oliveira-brett, A. M. (2008). Ultrasound extracted flavonoids from four varieties of Portuguese red grape skins determined by reversephase high-performance liquid chromatography with electrochemical detection. Analytica Chimica Acta, 630, 107-115. https://doi.org/10.1016/j.aca.2008.10.002.

Paixão, N., Perestrelo, R., Marques, J. C., \& Câmara, J. S. (2007). Relationship between antioxidant capacity and total phenolic content of red, rosé and white wines. Food Chemistry, 105, 204-214. https://doi.org/10.1016/j.foodchem.2007.04.017.

Prozil, S. O., Evtuguin, D. V., Silva, A. M. S., \& Lopes, L. P. C. (2014). Structural characterization of lignin from grape stalks. Journal of Agricultural and Food Chemistry, 62, 5420-5428. https://doi.org/10.1021/jf502267s.

Quideau, S., Deffieux, D., Douat-casassus, C., \& Pouysøgu, L. (2011). Natural products plant Polyphenols : Chemical properties, biological activities, and synthesis ** angewandte. Angewandte Chemie International Edition, 50, 586-621. https://doi.org/10. 1002/anie.201000044.

Re Pellegrini, N., Proteggente, A., Pannala, A., M, Y., \& Rice-Evans, C. (1999). Antioxidant activity applying an improved ABTS radical. Free Radical Biology \& Medicine, 26(98), 1231-1237.

Rodríguez Vasquero, M. J., Alberto, M. R., \& Manca de Nadra, M. C. (2007). Antibacterial 
effect of phenolic compounds from different wines. Food Control, 18, 93-101. https:// doi.org/10.1016/j.foodcont.2005.08.010.

Ruiz, E., Saenz, Y., Zaragoza, M., Rocha-Garcia, R., Martinez-Martinez, L., Arlet, G., et al. (2012). qnr, aac(6 ' )-Ib-cr and qepA genes in Escherichia coli and Klebsiella spp.: genetic environments and plasmid and chromosomal location. Journal of Antimicrobial Chemotherapy, 67, 886-897. https://doi.org/10.1093/jac/dkr548.

Rupasinghe, H. P. V., \& Clegg, S. (2007). Total antioxidant capacity, total phenolic content, mineral elements, and histamine concentrations in wines of different fruit sources. Journal of Food Composition and Analysis, 20(2), 133-137. https://doi.org/ https://doi.org/10.1016/j.jfca.2006.06.008.

Sarneckis, C. J., Dambergs, R. G., Jones, P., Mercurio, M., \& Herderich, M. J. (2006) Quantification of condensed tannins by precipitation with methyl cellulose: Development and validation of an optimised tool for grape and wine analysis. Australian Journal of Grape and Wine Research, 12, 39-49.

Scalbert, A. (1991). Antimicrobial properties of tannins. Phytochemistry, 30(12), 3875-3883. https://doi.org/https://doi.org/10.1016/0031-9422(91)83426-L.

Schieber, A. (2017). Side streams of plant food processing as a source of valuable Compounds: Selected examples. Annual Review of Food Science and Technology, 8(1), 97-112. https://doi.org/10.1146/annurev-food-030216-030135.

Szewczyk, K., Zidorn, C., Biernasiuk, A., Komsta, Ł., \& Granica, S. (2016). Polyphenols from Impatiens (Balsaminaceae) and their antioxidant and antimicrobial activities. Industrial Crops and Products, 86, 262-272. https://doi.org/https://doi.org/10.1016/ j.indcrop.2016.03.053.

Taguri, T., Tanaka, T., \& Kouno, I. (2004). Antimicrobial activity of 10 different plant polyphenols against bacteria causing food-borne disease. Biological and Pharmaceutical Bulletin, 27(12), 1965-1969.

Tesaki, S., Tanabe, S., Moriyama, M., Fukushi, E., Kawabata, J., \& Watanabe, M. (1999). Isolation and identification of an antibacterial compound from grape and its application to foods. Nippon Nogeikagaku Kaishi, 73(2), 125-128. https://doi.org/10. 1271/nogeikagaku1924.73.125.
Topalovic, A., \& Mikulic-Petkovsek, M. (2010). Changes in sugars, organic acids and phenolics of grape berries of cultivar Cardinal during ripening. Journal of Food Agriculture and Environment, 8(3\&4), 223-227.

Uttara, B., Singh, A. V., Zamboni, P., \& Mahajan, R. T. (2009). Oxidative stress and neurodegenerative Diseases: A review of upstream and downstream antioxidant therapeutic options. Current Neuropharmacology, 7, 65-74.

Vaquero, M. J. R., Alberto, M. R., \& de Nadra, M. C. M. (2007). Antibacterial effect of phenolic compounds from different wines. Food Control, 18, 93-101. https://doi.org/ 10.1016/j.foodcont.2005.08.010.

Vázquez-Armenta, F. J., Silva-Espinoza, B. A., Cruz-Valenzuela, M. R., González-Aguilar, G. A., Nazzaro, F., Fratianni, F., et al. (2017). Antibacterial and antioxidant properties of grape stem extract applied as disinfectant in fresh leafy vegetables. Journal of Food Science \& Technology, 54(10), 3192-3200. https://doi.org/10.1007/s13197-0172759-5.

Xu, C., Yagiz, Y., Hsu, W.-Y., Simonne, A., Lu, J., \& Marshall, M. R. (2014). Antioxidant, antibacterial, and antibiofilm properties of polyphenols from muscadine grape (vitis rotundifolia michx.) pomace against selected foodborne pathogens. Journal of Agricultural and Food Chemistry, 62(28), 6640-6649. https://doi.org/10.1021/ jf501073q.

Yam, T. S., Shah, S., \& Hamilton-Miller, J. M. (2006). Microbiological activity of whole and fractionated crude extracts of tea (Camellia sinensis), and of tea components. FEMS Microbiology Letters, 152(1), 169-174. https://doi.org/10.1111/j.1574-6968. 1997.tb10424.x.

Yang, J., Martinson, T. E., \& Hai, R. (2009). Phytochemical profiles and antioxidant activities of wine grapes. Food Chemistry, 116(1), 332-339. https://doi.org/10.1016/j. foodchem.2009.02.021.

Zhu, L., Zhang, Y., \& Lu, J. (2012). Phenolic contents and compositions in skins of red wine grape cultivars among various genetic backgrounds and originations. International Journal of Molecular Sciences, 13, 3492-3510. https://doi.org/10.3390/ ijms13033492. 